\title{
The Factors Which Lead Students' Dropout from Public Secondary Schools in Al'Ain City, Exploring It
}

\author{
Fatima Khamis Abdulla Alkaabi
}

Associate Professor

\section{Dr. Mohd Asri Bin Mohd Noor}

Faculty of Management \& Economics, University of Pendidikan Sultan Idris, Tanjung Malim, Malaysia

\section{Abstract}

For any instructive organization, understudies are generally significant. Colleges and schools have no an incentive without students. The instructive cycle is an incorporated interaction including the family, the school and the whole local area to arrive at viable yields. There are a number of factors that negatively affect at-risk students' retention in school and graduate such as socioeconomic status. Phenomenon of dropout where thousands of students dropped out is prevalent and constant in urban schools across the United States (Brown, 2015). This research is important for academic reason; it gives academic practitioners vital information that can be utilized to develop the education. The information was collected by interviews questions with students. The information collected were analyzed by using coding, theme and sub-nodes with Nvivo program. The research showed that the factors affect in Retention of secondary stage's students in Al Ain.

Keywords: drop-out, phenomenon, factors, student retention, socioeconomic status, coding, themes, sub-nodes

\section{Introduction}

The phenomenon of students dropping out of high school has also gained renewed attention, with researchers, educators and policy makers wanting to know how many students are dropping out, what causes dropout, and what may be done to prevent it (Heckman \&Paul,2007; Orfield,2004). The wonder of dropout is one of the principle issues that impede the instructive cycle specifically in the non-industrial nations (Eissa, 2016).

Students' dropout has both a negative personal effect and an economic impact on the individual and the community (Brown, 2015). Dropout is a disturbing issue, which influences the financial turn of events. Pupils' dropout does not only affect the 
community they belong to but also affects the nation at large. Pupils dropping out from schools leads to wasteful utilization of scarce educational resources without achieving the nation's educational aspirations. This does not mean well for healthy educational system and would have negative effect on the economy of the state because those who dropped out may create higher future costs (Segumba, 2015).

Most of the previous studies on student's performance focused on issues like teacher education, class environment, gender difference, teaching style, family educational background and socioeconomic factor (Singh, Malik, \& Singh, 2016). Economic and social development of a country depends on education (Ali, Jusof, Ali, Mokhta, \& Salamat, 2009).

\section{Problem Statement}

Educators warned against the decline in the demand of students in public and private schools for education in recent years and missing of motivation between students in the UAE, they explained that "most of the students are indifferent to studying, do not focus on explaining the teachers, and spend the school day between sleeping and playing", calling on the Ministry of Education to restructure its educational plans, policies and programs, to motivate students to learn, they attributed the problem to the lack of attractiveness of the curriculum contents, the absence of incentives from the teaching profession, the application of the three classroom system, the weak control of parents over their student children, and the weak communication between home and school, so the policies to improve students retention are very important. The students in the twelfth grade, emphasized that most students do not care to explain the teachers, or to study their lessons, and spend their school day between sleeping and playing, they added that this is due to their boredom from the existing teaching methods, from the many examinations, as well as the availability of other methods of learning outside the school, which keeps them from attending school, noting private lessons and academic summaries. (Alsoba'ei, 2011). However, the gap is no previous researches have been done on exploring factors which lead students to dropout in UAE.

In UAE, the high paces of non-appearance among understudies when public occasions and homeroom tests are a difficult that influences the instructive field and the school organization and projects a negative shadow on the instructive interaction. It also affects the annual plan of the lesson. School principals and parents confirmed that the high absentee rates among students after the holidays have become a phenomenon experienced by the departments of schools and teaching bodies and cast a negative shadow on the field of education, demanding the need to include some field activities in the curriculum that will reduce boredom and breathe the spirit of vitality among students. These will make the school environment more attractive to them. In addition, parents are also asked to bring their children to school so as not to miss the grades of assessment in the written and oral examinations. (Eisam, 2014). 


\section{Literature review}

All the instructive meetings in the UAE (which resulting and transferring the decisions of ministry of education) focus on developing the quality of education and finding solutions to general factors to attract students to the educational process, for example, Al Shihi ( member in the UAE Federal National Council (FNC) said in an educational conference that the statistics of students dropout, repeating a grade and achieving low examination results in public schools have become a cause of concern and called for the issue to be addressed (Al Serkal, 2018). But what are the factors which lead students to dropout, this investigation will spotlight on that point. Attaway and Bry, (2004); Nelson and Guerra, (2014) mentioned some of the specific factors that encourage students to education and their academic achievement (a) environmental such as family income; (b) parents level of education; (c) occupational status; (d) neighborhood environments; (e) school factors to include teacher expectations; and (f) school environment.

While there is no sensible and unsurprising definition, theoretical frameworks are characterized as any observational or semi experimental theory of social as well as psychological procedures, at various levels, that can be connected to the understanding of phenomena (Anafara \& Mertz, 2006; Fountain, 2014). Retention theories provide the theoretical orientation for the context of this study. The researcher investigated different theories of diligence and retention, in that discovering ideas which related to each theory.

To spotlight on factors or obstacles of dropout there were many theories that were studied included George Kuh's theory of student engagement. In addition, the researcher reviewed motivation theories such as Maslow's hierarchy of needs, Glasser's choice theory, the expectancy-value theory by Vroom and Need to achieve theory. So as to discover more profundity and to find more depth intrinsic and extrinsic motivation will also review. According to Bozack (2011), motivation research incredibly adds to the comprehension of ideas identified with student accomplishment. Also, the researcher in current research will review environmental and social affects through the social cognitive theory and the adaption with the different stress through attribution theory.

\section{Research Methodology}

The aim of the qualitative research is to explore the factors and influences that reduced retention of male and female students in the secondary stage of Al Ain schools as well as experiences that the students perceived as helpful to their persistence along the study trip.

This exploration depends on the data that can be gotten from understudies, educators and guardians. 


\subsection{Instruments}

The instrument in the qualitative research is the researcher. the researcher will use observation, interviews and documents data with students in Al Ain city who already drop out during the last 1-2 years, each participant will be informed in advance that the interview session will take about half an hour at the location determined by the participant himself. Also they will be informed by the numbers of questions, so the researcher will tell them there will be eleven questions through interview, the strategy of interview will be fact-to-face by asking questions, recording the answers to get every things from participations, taking notes and watching reactions to register the notes, during that the researcher will take permission from participations regarding any questions, also the researcher will not initiate any other communication with the participations outside the meeting procedure that relate to subject, also the researcher will not force any participant to complete this study. The name of participants will not be mentioned in the research.

\section{Data Analysis \& Result}

In the study, the researcher uses comprehending, synthesizing, theorizing and recontextualizing method to explore the factors that lead to student's dropout within different types of theories. The findings of the present study assist the educational officials in the formulation of effective retention policies. For example, the investigating is profound approach to understand what that variables lead to dropout. 


\begin{tabular}{|c|c|c|c|}
\hline Research Objectives & Research Questions & Theories & Data Analysis \\
\hline $\begin{array}{l}\text { 1.To explore the perceived factors } \\
\text { that contribute to students } \\
\text { dropping out of school in } \\
\text { secondary stage. }\end{array}$ & $\begin{array}{l}\text { 1. What perceived factors } \\
\text { contribute to students } \\
\text { dropping out from school in } \\
\text { secondary stage? }\end{array}$ & $\begin{array}{l}\text { *Retention } \\
\text { theory } \\
* \text { Choice theory } \\
\text { *Social } \\
\text { Cognitive } \\
\text { theory/ }\end{array}$ & $\begin{array}{l}\text { comprehending, } \\
\text { synthesizing, theorizing } \\
\text { re-contextualizing }\end{array}$ \\
\hline $\begin{array}{l}\text { 2. To explore the importance of the } \\
\text { family's socioeconomic status on } \\
\text { student's persistence in schools } \\
\text { setting. }\end{array}$ & $\begin{array}{l}\text { 2. What is the importance of } \\
\text { the family's socioeconomic } \\
\text { status on student's persistence } \\
\text { in schools setting? }\end{array}$ & $\begin{array}{l}* \text { Need to } \\
\text { achieve theory/ }\end{array}$ & $\begin{array}{l}\text { comprehending, } \\
\text { synthesizing, theorizing } \\
\text { re-contextualizing }\end{array}$ \\
\hline $\begin{array}{l}\text { 3. To identify what perceived } \\
\text { coping mechanisms students think } \\
\text { they need to implement as they } \\
\text { encounter stressors to adapt with } \\
\text { the factors that lead them to } \\
\text { dropout. }\end{array}$ & $\begin{array}{l}\text { 3. What coping mechanisms } \\
\text { do intermediate and secondary } \\
\text { students think they need to } \\
\text { implement as they encounter } \\
\text { stressors to adapt with the } \\
\text { factors that lead them to } \\
\text { dropout? }\end{array}$ & $\begin{array}{l}\text { *Attribution } \\
\text { theory }\end{array}$ & $\begin{array}{l}\text { comprehending, } \\
\text { synthesizing, theorizing } \\
\text { re-contextualizing }\end{array}$ \\
\hline
\end{tabular}




\begin{tabular}{|c|c|c|c|}
\hline $\begin{array}{l}\text { 4. To explore the students } \\
\text { perceived motivations to continue } \\
\text { their study or drop out. }\end{array}$ & $\begin{array}{l}\text { 4. What are the students } \\
\text { perceived motivations to } \\
\text { continue or drop out? }\end{array}$ & $\begin{array}{l}\text { *Intrinsic \& } \\
\text { Extrinsic } \\
\text { motivation } \\
\text { theory } \\
\text { *Social } \\
\text { Cognitive } \\
\text { Theory } \\
\text { *Hierarchy of } \\
\text { needs theory/ }\end{array}$ & $\begin{array}{l}\text { comprehending, } \\
\text { synthesizing, theorizing } \\
\text { re-contextualizing }\end{array}$ \\
\hline $\begin{array}{l}\text { 5. To explore policies that students } \\
\text { perceived can be implemented to } \\
\text { improve their retention in schools. }\end{array}$ & $\begin{array}{l}\text { 5. What policies students } \\
\text { perceived that can be } \\
\text { implemented to improve their } \\
\text { retention in the schools? }\end{array}$ & $\begin{array}{l}* \text { Retention } \\
\text { theory } \\
* \text { Social } \\
\text { Cognitive } \\
\text { Theory } \\
* \text { Hierarchy of } \\
\text { needs theory/ }\end{array}$ & $\begin{array}{l}\text { comprehending, } \\
\text { synthesizing, theorizing } \\
\text { re-contextualizing }\end{array}$ \\
\hline
\end{tabular}

\section{Finding}

The study included 21 respondents who participated in one-on-one interviews and follow up phone call interviews with the researcher. The information was collected from students who had dropped out of high school in Al-Ain city, where they were contacted and meetings were conducted with them at their convenience to find out the details of their lives and the reasons that led them to leave the study and monitor their feelings towards that.

This study involved 21 local participants who dropped out from high school in Al-Ain city. The respondents consisted of two males who are currently working in armed forces and dropped out of schools, and 19 females who are unemployed: some of them had family problems, others had relatives who were dropped out and family background of dropouts, others (female students) had old habits in marrying girls at a young age, others were not interested in studying, other students had family's financial problem and another group had family's business that played an important 
role in dropping out instead of being motivated. The information obtained during the interviews provided an opportunity to interpret the life experiences of the respondents, because the synchronous communication in a face-to-face interview provided the advantage to view social cues such as, voice, body language, intonation, and so forth.

The findings for the overall numbers of respondents' ages at the time of their dropped out: 3 students aged 20 years old, 3 students aged 19 years old, 3 students aged 18 years old, 8 students aged 22 years old, 2 students aged 17 years old and 2 students aged 16 years old.

\begin{tabular}{|l|l|}
\hline $\begin{array}{l}\text { Number of } \\
\text { Respondents }\end{array}$ & $\begin{array}{l}\text { Age when they } \\
\text { actually dropped }\end{array}$ \\
\hline 3 & 20 \\
\hline 3 & 19 \\
\hline 3 & 18 \\
\hline 8 & 22 \\
\hline 2 & 17 \\
\hline 2 & 16 \\
\hline
\end{tabular}

After completing all the interview sessions, the coding process began by entering all the data in Nvivo program. During this level of coding, distinct concepts and categories were identified and separated into codes. Next, the data was revisited to begin with the axial coding process. During this process, emergent codes were revealed. The emergent codes were identified and were presented during this level of coding. Lastly, the final level of coding process was completed. In the refining and transferring of the codes level, the final concepts and categories were identified and transported by using Nvivo program. This program had assisted in the process of pinpointing specific themes and sub-themes of the data.

Also based on the analysis, it was found that the influential factors affecting the dropouts among the participants from the most to the least were identified as follows (Figure 6):

- External factors with sub-nodes of family problems, health reasons, marriage, low scores, friends' simulation, teachers and curriculum

- Policies and instruction

- Internal factors with sub-nodes of personal needs including psychological, social and safety need

- Socioeconomic factors with sub-nodes of types of job

- Self-motivation and social motivation at the same level

- Finally, coping mechanism

The analysis of reveals answers to educators and parents about what factors influence them to drop out from secondary schools, and what types of motivation they 
need. Based on the emerging themes, more often than not students dropped out because of external factors (family problems, behavior of teachers, hard of curriculum, friends' or a peer simulation), lack of Policies and instruction preventing them from drop out, internal factors, socioeconomic factors, lack of social motivation and lack of coping mechanism in difficult conditions.

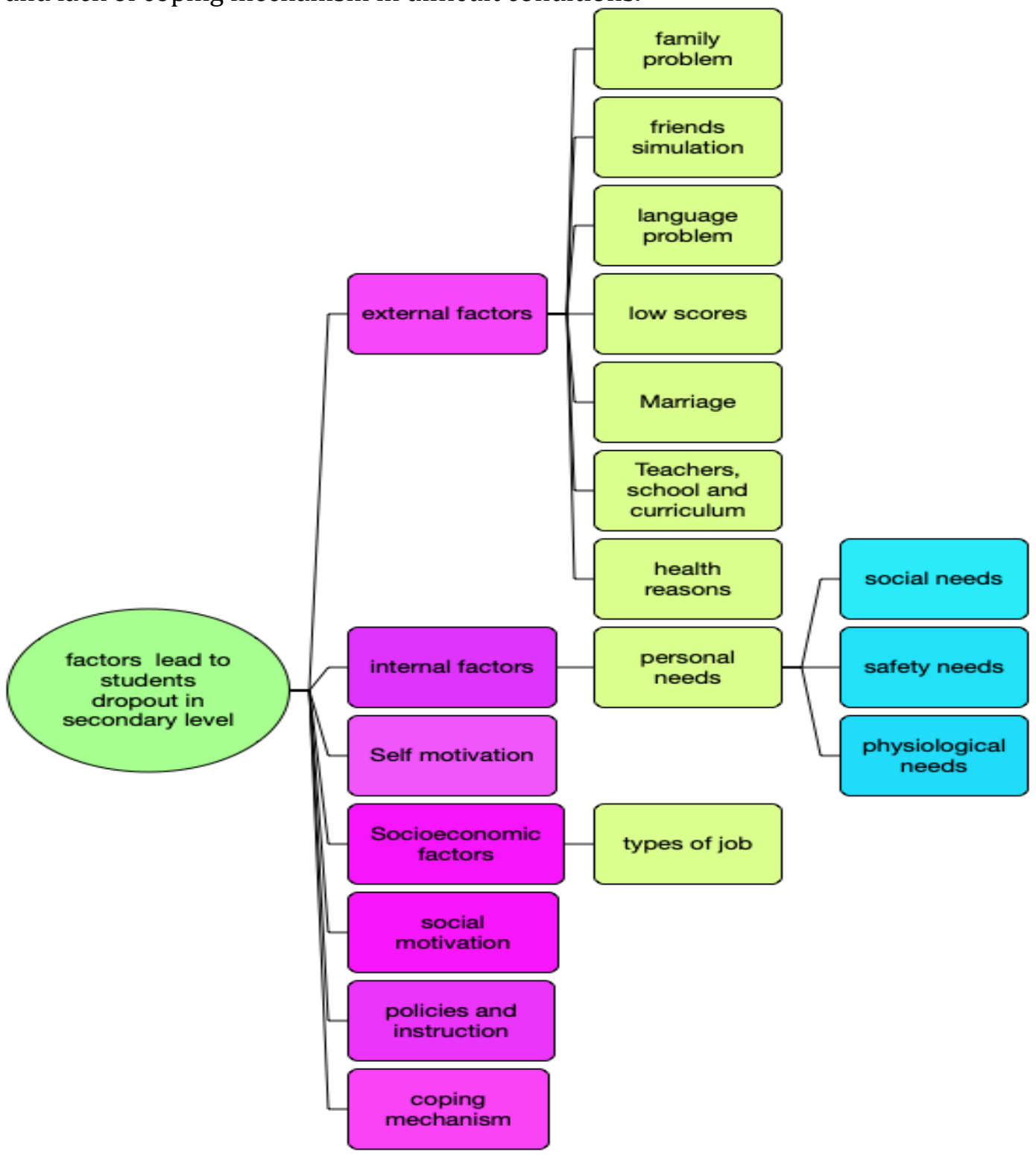

Dropouts Factors (from Nvivo DATA ANALYSIS). Show the themes and sub-nodes 


\section{References}

[1] Ali, N., Jusof, K., Ali, S., Mokhtar, N., \& Salamat, A.S.A. (2009). The Factors Influencing

[2] Students' Performance at Universiti Teknologi Mara Kedah, Malaysia. Management Science and

[3] Engineering, 3(4), P 81-90

[4] Al Serkal, Mariam, M. (2018). UAE Minister to be questioned over students' low scores. Gulf

[5] News.

[6] Alsoba'ei, W. (2011). Educators: Students 'motivation to education is declining. Emaratalyom. Dubai.

[7] Anafara, Jr., V. A. \& Mertz, N. (2006). Theoretical frameworks in qualitative research. Thousand Oaks, CA: Sage Publications, Inc.

[8] Attaway, N. M., \& Bry, B. H. (2004). Parenting style and black adolescents' academic

[9] achievement. Journal of Black Psychology, 30(2), 229-245. doi:10.1177/0095798403260720

[10] Bozack, A. (2011). Reading between the lines: Motives, beliefs, and achievement in adolescent

[11] boys. The High School Journal, (94)2, 58-76.

[12] Brown, K.E. (2015). The Link Between Leadership and Reduced Dropout Rates. Walden University.

[13] Eisam aldin. (2014). Official leave holidays shake schools. Albayan. UAE.

[14] Retrieved from:

https://www.albayan.ae/across-the-uae/education/2014-05-31-1.2134917

[15] Eissa, R. (2016). Child labor and its relation to school dropout A field study of a sample of

[16] abandoned working children - Biskra. University of Mohammed Khader Biskra.

[17] Fountain, S. (2014). Stopping out: Experiences of African American females at a Midwestern

[18] community college. Retrieved from: http://lib.dr.iastate.edu/etd/14161

[19] Heckman, J. J. \& Paul, L. (2007). "The American High School Graduation Rate: Trends and

[20] Levels." NBER (Working paper W13670). Available online: http://ssrn.com/ abstract $=1073650$

[21] Nelson, S. W., \& Guerra, P. L. (2014). Educator beliefs and cultural knowledge:

[22] implications for school improvement efforts. Educational Administration Quarterly, 50(1) 67-95. doi: 10.1177/0013161X13488595

[23] Orfield, G. (2004). Dropouts in America: Confronting the Graduation Rate Crisis. Cambridge, 
[24] MA: Harvard Education Publishing Group.

[25] Segumba, S, I. (2015). Factors Leading to Problems of Drop Out in Primary School Pupils in

[26] Temeke District. University of Tanzania.

[27] Singh, S.P., Malik,S \& Singh,P.(2016). Factors Affecting Academic Performance of Students.

Volume5. Issue:4 